\title{
Influence of Lead Nitrate on Sulfurizing Flotation of a Copper-Cobalt Oxide Ore
}

\author{
Meschack Mukunga MUANDA ${ }^{1, *}$ and Pele Pascal Daniel OMALANGA ${ }^{2}$ \\ ${ }^{I}$ Department of Chemical Engineering, Faculty of Engineering, Alexandria University, Alexandria, Egypt \\ ${ }^{2}$ Department of Chemical Engineering, Faculty of Polytechnic, University of Lubumbashi, Lubumbashi, \\ Democratic Republic of the Congo
}

('Corresponding author’s e-mail: muandamukunga@gmail.com)

Received: 1 January 2020, Revised: 7 June 2020, Accepted: 9 July 2020

\begin{abstract}
Copper-cobalt oxide ores contain several minerals that are economically treatable by concentration techniques. The most used technique is froth flotation in which selective reagents are used to recover more valuables. It is, therefore, important to examine the optimal doses of those reagents while investigating the behaviors of minerals at the same time. This study explored the influence of lead nitrate $\mathrm{Pb}\left(\mathrm{NO}_{3}\right)_{2}$ on the froth flotation of oxide ore to increase valuable metals recoveries. Four factors were investigated including $\mathrm{Pb}\left(\mathrm{NO}_{3}\right)_{2}$ dosage, its conditioning, its addition dose in the $2^{\text {nd }}$ fraction, and sulfidiser dosage. Other parameters were kept constant. The optimum was found at $25 \mathrm{~g} / \mathrm{t} \mathrm{of} \mathrm{Pb}\left(\mathrm{NO}_{3}\right)_{2}$, conditioning together with sodium silicate $\left(\mathrm{Na}_{2} \mathrm{SiO}_{3}\right)$ for $5 \mathrm{~min}$, the addition of $5 \mathrm{~g} / \mathrm{t}$ of $\mathrm{Pb}\left(\mathrm{NO}_{3}\right)_{2}$ in the $2^{\text {nd }}$ fraction, and 3,000 g/t of sulfidiser. Recoveries in concentrates were $79.51 \%$ Copper $(\mathrm{Cu})$ and 60.27 $\%$ Cobalt $(\mathrm{Co})$, with grades of 9.49 and $0.67 \%$, respectively. The conclusion was that the use of $\mathrm{Pb}\left(\mathrm{NO}_{3}\right)_{2}$ can considerably improve copper and cobalt recoveries.
\end{abstract}

Keywords: Cobalt, Copper, Lead nitrate, Oxide ore, Xanthate, Sulfurizing flotation

\section{Introduction}

In the Democratic Republic of the Congo, most of the concentration plants treat oxide minerals in ranges $1.5-3 \%$ Copper grade and $0.2-1 \%$ Cobalt grade $[1,2]$. The principal used method of concentration is sulfurizing flotation, producing final concentrate with grades of $10-16 \%$ Copper and $0.6-1.2 \%$ Cobalt, and yields of $50-70$ and $30-60 \%$, respectively. However, tailings contain a considerable amount of valuable metals.

According to Shengo [2], the mineralogy of the Kamfundwa mine (located in Haut-Katanga Province, the Democratic Republic of the Congo) is constituted by oxide minerals containing mainly Copper and Cobalt. Malachite $\left(\mathrm{Cu}_{2} \mathrm{CO}_{3}(\mathrm{OH})_{2} \cdot \mathrm{H}_{2} \mathrm{O}\right)$, cuprite $\left(\mathrm{Cu}_{2} \mathrm{O}\right)$, pseudomalachite, chrysocolla $\left(\mathrm{CuO} . \mathrm{SiO}_{2} \cdot 2 \mathrm{H}_{2} \mathrm{O}\right)$, and heterogenite $\left(\mathrm{CoO} .2 \mathrm{Co}_{2} \mathrm{O}_{3} \cdot 6 \mathrm{H}_{2} \mathrm{O}\right)$ are among those minerals. Silica constitutes the gangue mineral (about $95 \%$ ). However, malachite and heterogenite are abundant. The following reagents are frequently used: sodium hydrosulfide (NaHS) as sulfidiser, potassium amylxanthate (PAX: $\left.\mathrm{C}_{5} \mathrm{H}_{11} \mathrm{OCS}_{2} \mathrm{Na}\right)$ as a collector, sodium silicate $\left(\mathrm{Na}_{2} \mathrm{SiO}_{3}\right)$ as depressant and dispersant [3], senfroth (G41) as frother, and dolomitic mixture (MIX) as a mineralizing agent. It has been shown by Bulatovic [4], Blazy [5], and Wills [6] that lead, zinc, and copper oxide ores are hardly floatable because they are more soluble in comparison to correspondent sulfide ore. On another side, cobalt oxide ores are easily floatable by palm oil but the process is not selective and produces poor rougher concentrate [7]. On the other hand, the use of certain metal ions can largely improve the recovery of some minerals in froth flotation [8].

Several authors [9-12] have studied the effect of the lead ion as an activator of many minerals. According to their results, the addition of $\mathrm{Pb}\left(\mathrm{NO}_{3}\right)_{2}$ enhanced recoveries of valuable metals by a 
http://wjst.wu.ac.th

mechanism of adsorption of lead on mineral surfaces and coordination of collector with lead ions. Miller et al. [13] have also studied PAX and $\mathrm{Pb}\left(\mathrm{NO}_{3}\right)_{2}$ effects on the pyrite surface. It has been shown that the addition of those reagents created the establishment of a hydrophobic pyrite surface. Liuyin et al. [14] also demonstrated that $\mathrm{Pb}\left(\mathrm{NO}_{3}\right)_{2}$ was a good activator for rare earth flotation.

In contrast to Du Plessis et al. [15], the hydrophobic pyrite surface state was beneficial when a significant concentration of cyanide was added into pulp by using $\mathrm{Pb}\left(\mathrm{NO}_{3}\right)_{2}$ and $\mathrm{PAX}$ as activator and collector, respectively. Leppinen et al. [16]; Zohir and Djamel [17] investigated Fourier-transform infrared spectroscopy (FTIR) and scanning electron micrograph (SEM) techniques. In their study, they observed the adsorption of xanthate on galena surfaces consisting of exchange between xanthate and hydroxide. The mechanism was followed by the formation of dixanthogen $\left(\mathrm{X}_{2}\right)$ and its diffusion across the surface. On the other hand, 2 mechanisms occurred during the absorption of xanthate on the sulfide mineral $[18,19]$. In the $1^{\text {st }}$ one, called chemisorption, there was the formation of a bond with lead atoms at the sulfide surface from adsorbed xanthate molecule. In the $2^{\text {nd }}$ one, called electrochemical, there was the production of oxidation product species rending the sulfide mineral hydrophobic [20,21].

According to Gang [11] and Poling et al. [19], activation of galena by copper took place at $\mathrm{pH} 9.5$ and Copper Amylxanthate (CuAX) was formed after the addition of PAX, rending galena surface strongly hydrophobic. On another side, the formation of Lead Xanthate $\left(\mathrm{PbX}_{2}\right)$ species also contributes to the hydrophobicity of the surface Eq. (1).

$P b S+2 X^{-} \rightarrow P_{b X_{2}}+S^{0}+2 e^{-}$

It is known that flotation efficiency depends on several of parameters such as particle size, pulp density, water quality, $\mathrm{pH}$, and reagent dosage [22,23]. In this paper, flotation tests in simple roughing were performed by using PAX (300 g/t) as primary collector, $\mathrm{NaSiO}_{3}(300 \mathrm{~g} / \mathrm{t})$ as gangue depressant and dispersant, G41 $(90 \mathrm{~g} / \mathrm{t})$ as a frother, MIX (300 g/t) as a secondary collector, NaHS $(3,000 \mathrm{~g} / \mathrm{t})$ as sulfidiser. Only $\mathrm{Pb}\left(\mathrm{NO}_{3}\right)_{2}$ dose was varied and $\mathrm{pH}$ was natural.

\section{Material and methods}

\section{Sampling}

The Sample was collected from the Kamfundwa deposit and prepared for analysis. Atomic absorption spectroscopy has revealed the results presented in Table 1.

Table 1 Sample AAS/ICP analysis of raw ore.

\begin{tabular}{lc}
\hline Component & Content (\%) \\
\hline Total Copper $\left(\mathrm{Cu}_{\text {tot }}\right)$ & 2,55 \\
Copper oxide $\left(\mathrm{Cu}_{\text {ox }}\right)$ & 2,10 \\
Total Cobalt $\left(\mathrm{Co}_{\text {tot }}\right)$ & 0,20 \\
Cobalt oxide $\left(\mathrm{Co}_{\text {ox }}\right)$ & 0,12 \\
Total Calcium oxide $\left(\mathrm{CaO}_{\text {tot }}\right)$ & 0,38 \\
Soluble Calcium oxide $\left(\mathrm{CaO}_{\text {sol }}\right)$ & 0,11 \\
\hline
\end{tabular}

\section{Reagents}

MIX $1.2 \%$ was prepared by mixing $1.08 \mathrm{~g}$ gasoil $(90 \%)$ and $0.12 \mathrm{~g}$ of synthetic acids (10\%) named rinkalore 10. A small amount of sodium carbonate $1.2 \%\left(\mathrm{Na}_{2} \mathrm{CO}_{3}\right)$ was added to emulsify the mixture. Note that rinkalore 10 is a mixture of fatty synthetic acids.

PAX $1.2 \%$, NaHS $12 \%$ and $\mathrm{Na}_{2} \mathrm{SiO}_{3} 30 \%$ were prepared and $\mathrm{G} 41$ was used pure. Finally, $\mathrm{Pb}\left(\mathrm{NO}_{3}\right)_{2} 1.2 \%$ was prepared. Eq. (2) below was used to transform $\mathrm{g} / \mathrm{t}$ to milliliter. 
http://wjst.wu.ac.th

$\mathrm{V}=\frac{\text { mass of ore sample }(\mathrm{kg}) \times \text { reagent dose }(\mathrm{g} / \mathrm{t})}{\text { reagent concentration }(\mathrm{g} / \mathrm{l})}$

where $\mathrm{V}=$ volume of reactant

\section{Equipment}

The following equipment was used for flotation tests: flotation machine DENVER, graduated vessels for reagents, laboratory mill, wash-bottle of $1 \mathrm{~L}$, flotation cell of $2.5 \mathrm{~L}$, Erlenmeyer, SARTORIUS electronic balance, panels, $\mathrm{pH}$ meter, propipette, pallet, and drier.

\section{Grinding}

Grinding of the sample for 5, 10, 15, 20, and $25 \mathrm{~min}$, respectively, drying, and sieving enabled researchers to determine the optimal time to achieve the liberation of valuable particles (Figure 1). After 22 min of grinding, $70 \%$ of solid particles passed on a $75 \mu \mathrm{m}$ sieve. According to Figure 2, about 20.135 $\%$ of Copper particles and $18.561 \%$ of Cobalt particles were above the size of $75 \mu \mathrm{m}$.

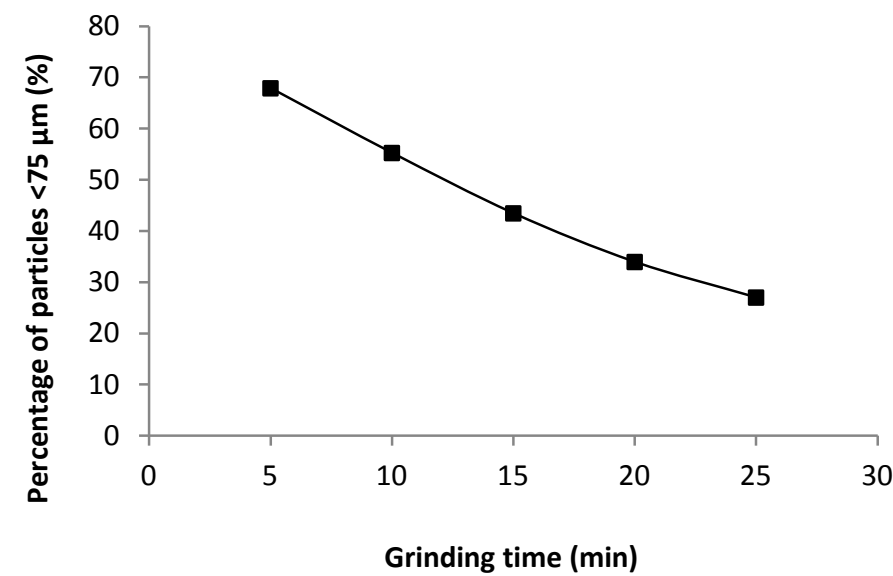

Figure 1 Sample grinding curve.

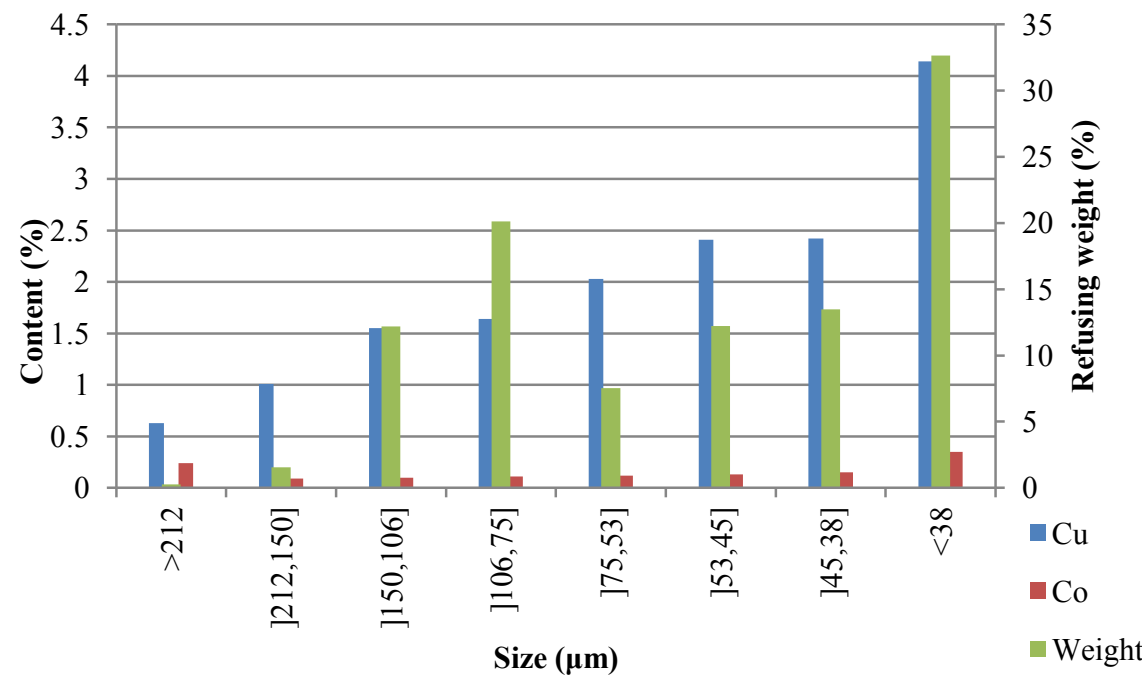

Figure 2 Sample sizing. 
http://wjst.wu.ac.th

\section{Flotation test}

Before flotation tests with $\mathrm{Pb}\left(\mathrm{NO}_{3}\right)_{2}$, the flotation test in simple rougher was done under reference conditions (Figure 3). One $\mathrm{kg}$ of sample was mixed with $1 \mathrm{~L}$ of water for grinding for $22 \mathrm{~min}$. Pulp with a specific weight of $1,340 \mathrm{~g} / \mathrm{L}$ was transferred into a flotation cell of $2.5 \mathrm{~L}$ under a speed impeller of 1,200 trs $/ \mathrm{min}$. $\mathrm{Na}_{2} \mathrm{SiO}_{3}, \mathrm{MIX}$, NaHS, PAX, and G41 were added fractionally for conditioning before open-air admission. The conditioning times of $\mathrm{Na}_{2} \mathrm{SiO}_{3}, \mathrm{MIX}, \mathrm{NaHS}, \mathrm{PAX}$, and G41 were 5, 2, 3, 2, and $1 \mathrm{~min}$, respectively. Sixty percent of PAX, and NaHS, were added in the head concentration and the $40 \%$ remaining were fractionally added in the other concentrations. After the collection of 6 concentrates of 2 min and tailings, they were sent to the lab for analysis to determine copper and cobalt contents.

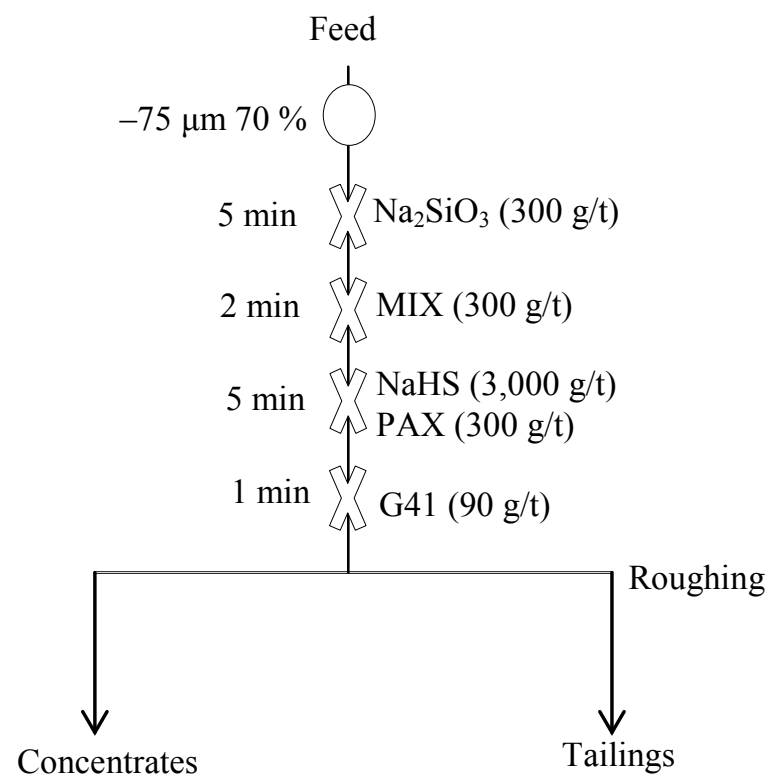

Figure 3 Flotation scheme under reference conditions.

\section{Results and discussion}

By maintaining constant parameters as seen in Figure 3, 4 factors were investigated to find out the effects of $\mathrm{Pb}\left(\mathrm{NO}_{3}\right)_{2}$. Table 2 and Figure 4 show the results of the flotation test under reference conditions. The final concentrate had a content of $8.31 \%$ copper with a recovery of $75.52 \%$ while the content of cobalt was $0.54 \%$ with a recovery of $61 \%$. 
http://wjst.wu.ac.th

Table 2 Contents and yields of Copper and Cobalt after flotation under reference conditions.

\begin{tabular}{ccccc}
\hline \multirow{2}{*}{ Fractions (concentrates) } & \multicolumn{2}{c}{ Copper } & \multicolumn{2}{c}{ Cobalt } \\
\cline { 2 - 5 } & Content (\%) & Yield (\%) & Content (\%) & Yield (\%) \\
\hline A & 22.55 & 28.81 & 0.81 & 12.87 \\
A + B & 21.37 & 54.55 & 1 & 31.66 \\
A + B + C & 16.67 & 64.59 & 0.86 & 41.4 \\
A + B + C + D & 12.21 & 69.16 & 0.69 & 48.7 \\
A + B + C + D + E & 9.72 & 72.75 & 0.6 & 55.3 \\
A + B + C + D + E + F & 8.31 & 75.52 & 0.54 & 61 \\
Tailings & 0.77 & 24.48 & 0.1 & 39 \\
Feed & 2.45 & 100 & 0.2 & 100 \\
\hline
\end{tabular}

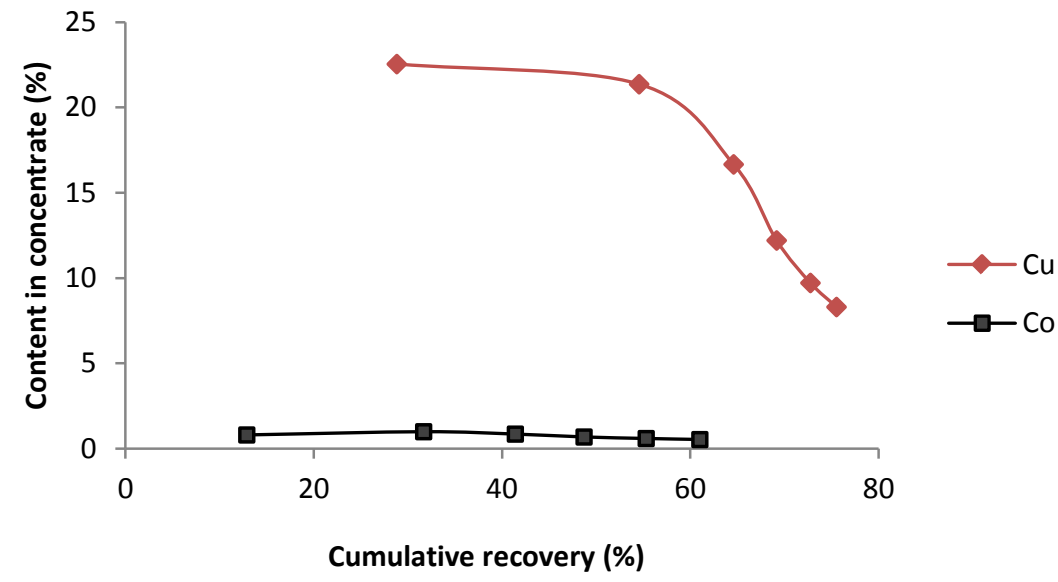

Figure 4 Reference flotation test without $\mathrm{Pb}\left(\mathrm{NO}_{3}\right)_{2}$.

Influence of $\mathrm{Pb}\left(\mathrm{NO}_{3}\right)_{2}$

To determine the optimal dose of $\mathrm{Pb}\left(\mathrm{NO}_{3}\right)_{2}, 5,25,50,75$, and $100 \mathrm{~g} / \mathrm{t}$ were used, and results were obtained (Figures 5 and 6). It could be overserved that for copper recovery, the difference was viewed in head concentrates and there was a similarity for rougher concentrates; for cobalt recovery, $25 \mathrm{~g} / \mathrm{t}$ was directly considered as the optimal dose.

Table 3 Influence dose of $\mathrm{Pb}\left(\mathrm{NO}_{3}\right)_{2}$ on copper and cobalt recoveries.

\begin{tabular}{ccccccc}
\hline \multirow{2}{*}{$\begin{array}{c}\text { Dose of } \\
\mathbf{P b}\left(\mathbf{N O}_{\mathbf{3}}\right)_{\mathbf{2}} \mathbf{( g / t )}\end{array}$} & Feed & Concentrate & $\begin{array}{c}\text { Final } \\
\text { recovery }\end{array}$ & Feed & Concentrate & $\begin{array}{c}\text { Final } \\
\text { recovery }\end{array}$ \\
\cline { 2 - 7 } & 26.24 & 8.09 & 81.44 & 0.84 & 0.56 & 77.7 \\
25 & 27.68 & 11.24 & 76.83 & 1.16 & 0.66 & 73.89 \\
50 & 20.92 & 6.62 & 83.47 & 0.89 & 0.43 & 70.65 \\
75 & 20.2 & 8.16 & 79.99 & 0.68 & 0.51 & 56.47 \\
100 & 16.81 & 7.68 & 79.74 & 0.64 & 0.46 & 61.89 \\
\hline
\end{tabular}


http://wjst.wu.ac.th

It is observed in Table 3 that the maximum recoveries of both copper and cobalt were observed at $25 \mathrm{~g} / \mathrm{t}$ of $\mathrm{Pb}\left(\mathrm{NO}_{3}\right)_{2}$, producing a concentrate at $11.24 \%$ Copper and $0.66 \%$ Cobalt with yields of 76.83 and $73.89 \%$, respectively. That dose was considered and used for the following flotation tests.

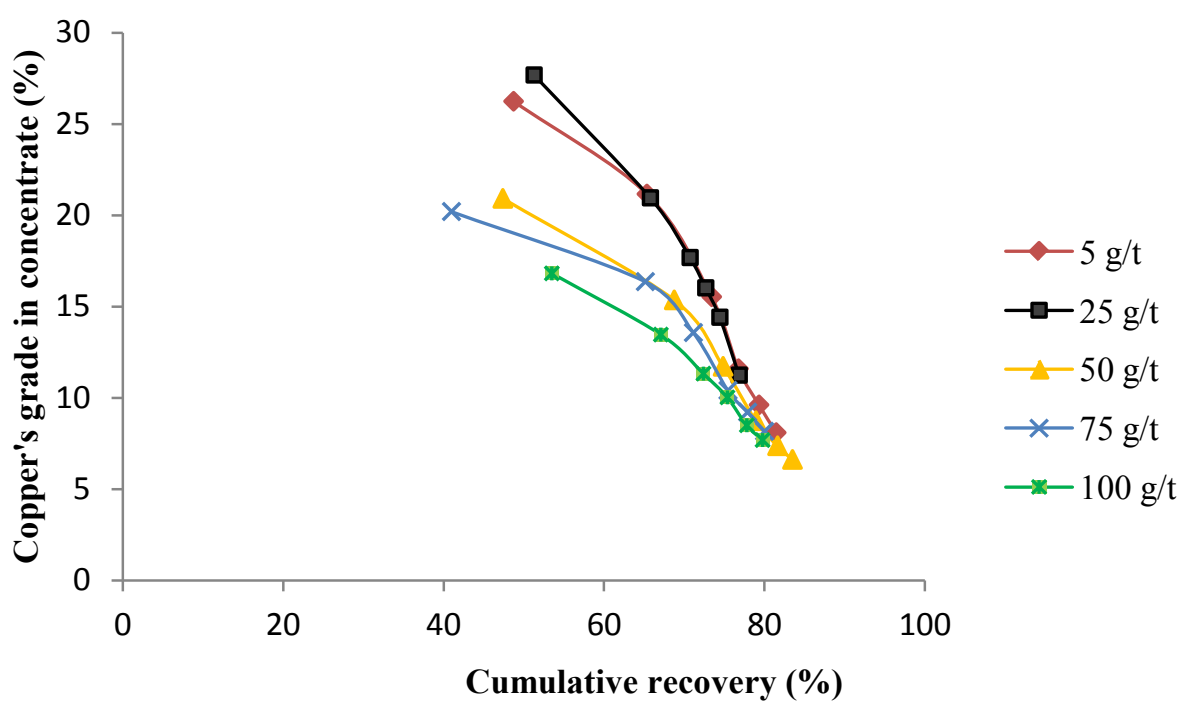

Figure 5 Influence of $\mathrm{Pb}\left(\mathrm{NO}_{3}\right)_{2}$ on copper recovery.

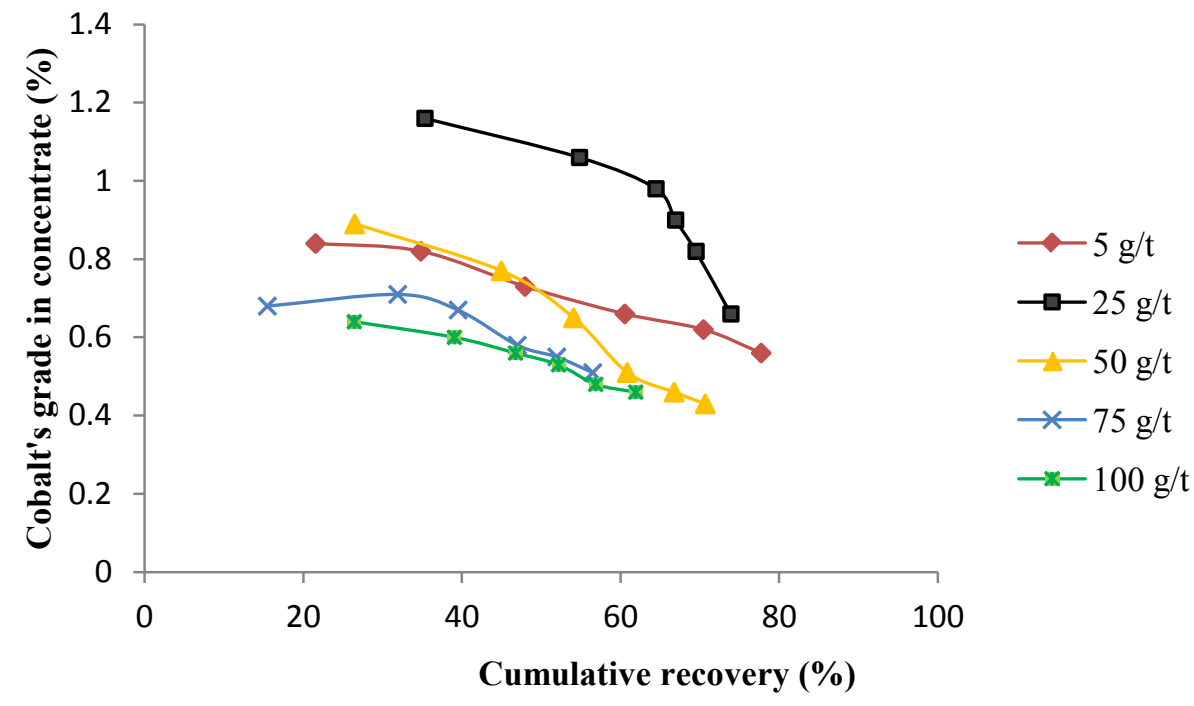

Figure 6 Influence of $\mathrm{Pb}\left(\mathrm{NO}_{3}\right)_{2}$ on cobalt recovery. 
The increase in the dose of $\mathrm{Pb}\left(\mathrm{NO}_{3}\right)_{2}$ leads to the excessive production of lead hydroxide $\left(\mathrm{Pb}(\mathrm{OH})_{2}\right)$ which is soluble in solution and thereby prevents the selectivity of the frother and the collection. Eqs. (3) and (4).

$$
\begin{aligned}
& \mathrm{NaSH}+\mathrm{H}_{2} \mathrm{O} \rightarrow \mathrm{Na}^{+}+\mathrm{OH}^{-}+\mathrm{H}_{2} \mathrm{~S} \\
& \mathrm{~Pb}\left(\mathrm{NO}_{3}\right)_{2}+\mathrm{OH}^{-} \rightarrow \mathrm{Pb}^{2+}+\mathrm{OH}^{-}+2 \mathrm{NO}_{3}^{-}
\end{aligned}
$$

Influence of conditioning of $\mathrm{Pb}\left(\mathrm{NO}_{3}\right)_{2}$

Four flotation tests have been done to study the effect of conditioning of $\mathrm{Pb}\left(\mathrm{NO}_{3}\right)_{2}$ :

- The conditioning for 5 min before the addition of $\mathrm{Na}_{2} \mathrm{SiO}_{3}$

- The addition without conditioning

- The co-conditioning with $\mathrm{Na}_{2} \mathrm{SiO}_{3}$ for 5 min

Table $4 \mathrm{~Pb}\left(\mathrm{NO}_{3}\right)_{2}$ conditioning influences on recoveries of both Copper and Cobalt.

\begin{tabular}{lcccccc}
\hline \multirow{2}{*}{ Conditioning } & \multicolumn{3}{c}{ Copper analysis (\%) } & \multicolumn{2}{c}{ Cobalt analysis (\%) } \\
\cline { 2 - 6 } & Feed & Concentrate & $\begin{array}{c}\text { Final } \\
\text { recovery }\end{array}$ & Feed & Concentrate & $\begin{array}{c}\text { Final } \\
\text { recovery }\end{array}$ \\
\hline 5 min before $\mathrm{Na}_{2} \mathrm{SiO}_{3}$ & 32.81 & 7.72 & 82.88 & 1.2 & 0.47 & 72.68 \\
$\mathrm{Without}$ conditioning with & 32.34 & 5.81 & 86.65 & 1.15 & 0.36 & 80.66 \\
$\mathrm{Na}_{2} \mathrm{SiO}_{3}$ & 30.9 & 6.43 & 87.27 & 1.15 & 0.35 & 82.58 \\
$\mathrm{With}$ & & & & & & \\
\hline
\end{tabular}

$\mathrm{Na}_{2} \mathrm{SiO}_{3}$ was conditioned for $5 \mathrm{~min}$ in all cases.

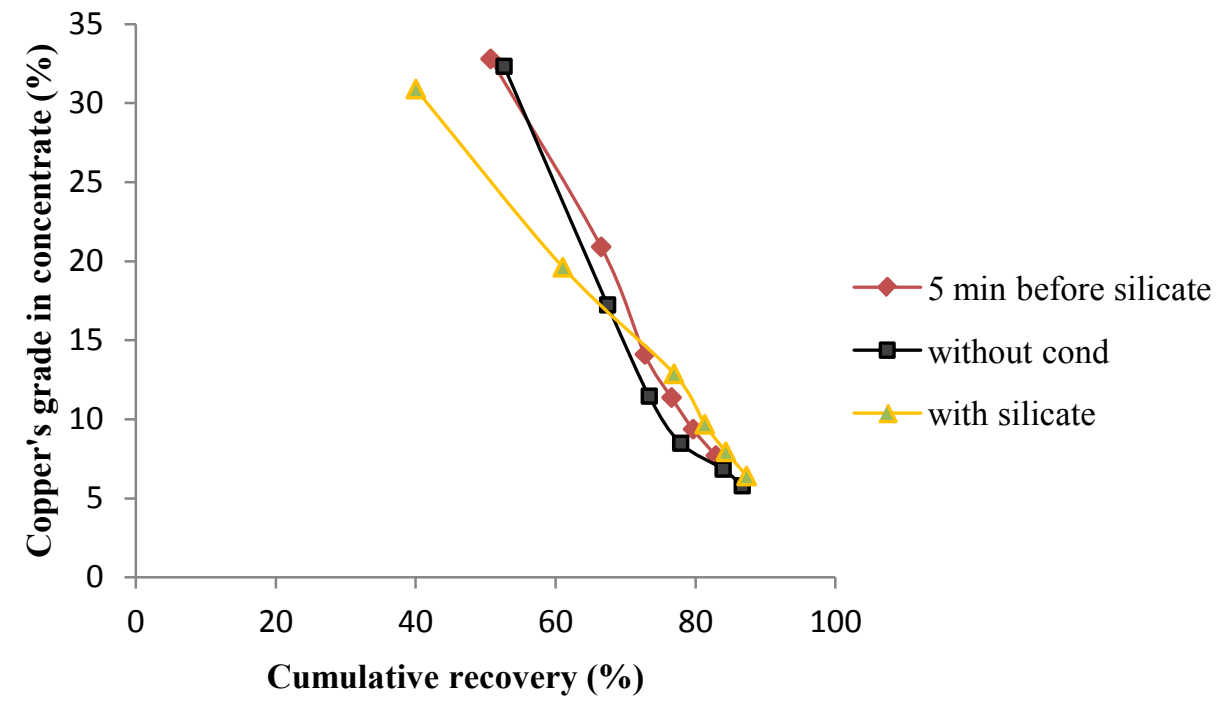

Figure 7 Effect of $\mathrm{Pb}\left(\mathrm{NO}_{3}\right)_{2}$ conditioning on copper recovery. 
In contrast to Figures 7 and 8, and Table 4; Copper and Cobalt recoveries are little sensitive to the variation of conditioning time of $\mathrm{Pb}\left(\mathrm{NO}_{3}\right)_{2}$ and rougher concentrates are nearly the same. It can also be said that $\mathrm{Pb}\left(\mathrm{NO}_{3}\right)_{2}$ is rapidly soluble in solution reason why there is a similarity for all the cases. Recoveries of both copper and cobalt are high when $\mathrm{Pb}\left(\mathrm{NO}_{3}\right)_{2}$ is added together with $\mathrm{Na}_{2} \mathrm{SiO}_{3}$ for a conditioning time of $5 \mathrm{~min}$. The rougher concentrate is produced with $6.43 \%$ Copper grade and $0.36 \%$ Cobalt grade, and yields of 87.27 and $82.58 \%$, respectively.

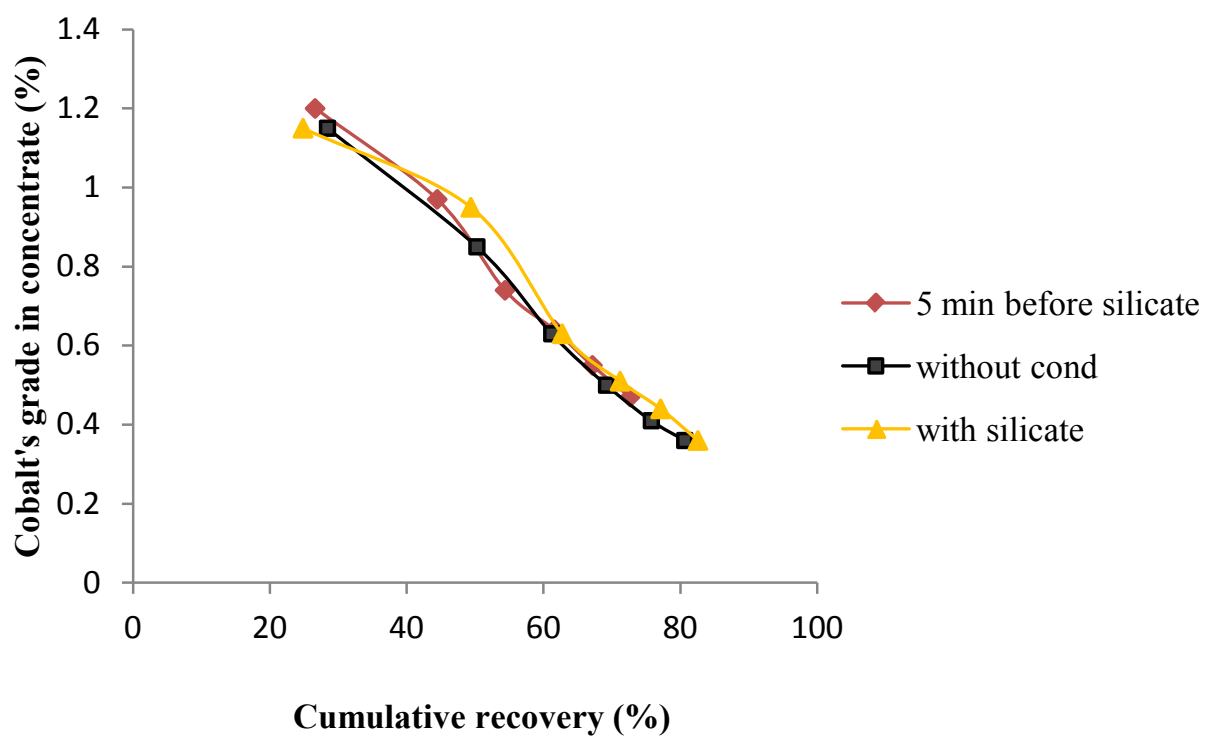

Figure 8 Effect of $\mathrm{Pb}\left(\mathrm{NO}_{3}\right)_{2}$ conditioning on cobalt recovery.

\section{Influence of $\mathrm{Pb}\left(\mathrm{NO}_{3}\right)_{2}$ addition}

The addition of $\mathrm{Pb}\left(\mathrm{NO}_{3}\right)_{2}$ was investigated to extend its effect on selectivity. However, 5, 10, 15, and $20 \mathrm{~g} / \mathrm{t}$ of $\mathrm{Pb}\left(\mathrm{NO}_{3}\right)_{2}$ respectively were added in the $2^{\text {nd }}$ fraction, after prior addition of $25 \mathrm{~g} / \mathrm{t}$ for $5 \mathrm{~min}$ of conditioning time with $\mathrm{Na}_{2} \mathrm{SiO}_{3}$. The following table shows the influence of the $\mathrm{Pb}\left(\mathrm{NO}_{3}\right)_{2}$ addition on recoveries.

Table 5 Influence of $\mathrm{Pb}\left(\mathrm{NO}_{3}\right)_{2}$ addition on recoveries of both Copper and Cobalt.

\begin{tabular}{ccccccc}
\hline \multirow{2}{*}{$\begin{array}{c}\text { Dose of } \mathbf{P b}\left(\mathrm{NO}_{\mathbf{3}}\right)_{\mathbf{2}} \\
(\mathbf{g} / \mathbf{t})\end{array}$} & \multicolumn{3}{c}{ Copper analysis $(\%)$} & \multicolumn{3}{c}{ Cobalt analysis $(\%)$} \\
\cline { 2 - 7 } & Feed & Concentrate & Final recovery & Feed & Concentrate & Final recovery \\
\hline 5 & 29.23 & 9.49 & 79.51 & 1.26 & 0.67 & 60.27 \\
10 & 35.8 & 9.35 & 76.65 & 1.14 & 0.64 & 61.91 \\
15 & 27.91 & 7.04 & 83.44 & 1.12 & 0.44 & 74.42 \\
20 & 23.47 & 8.93 & 79.01 & 0.94 & 0.53 & 64.24 \\
\hline
\end{tabular}


According to results shown in Figures 9 and 10, the addition of $\mathrm{Na}_{2} \mathrm{SiO}_{3}$ has a low influence on recovery and there is a demarcation at $15 \mathrm{~g} / \mathrm{t}$ on the recoveries of both copper and cobalt. The optimal dose addition was $5 \mathrm{~g} / \mathrm{t}$ and with yields of $79.51 \%$ Copper and $60.27 \%$ Cobalt with grades of 9.49 and $0.67 \%$, respectively.

As shown in Eqs. (3) and (4), increasing the dose of $\mathrm{Pb}\left(\mathrm{NO}_{3}\right)_{2}$ increases the $\mathrm{Pb}(\mathrm{OH})_{2}$ concentration. This situation disadvantages the collection of valuable particles and prevents the action of the collector.

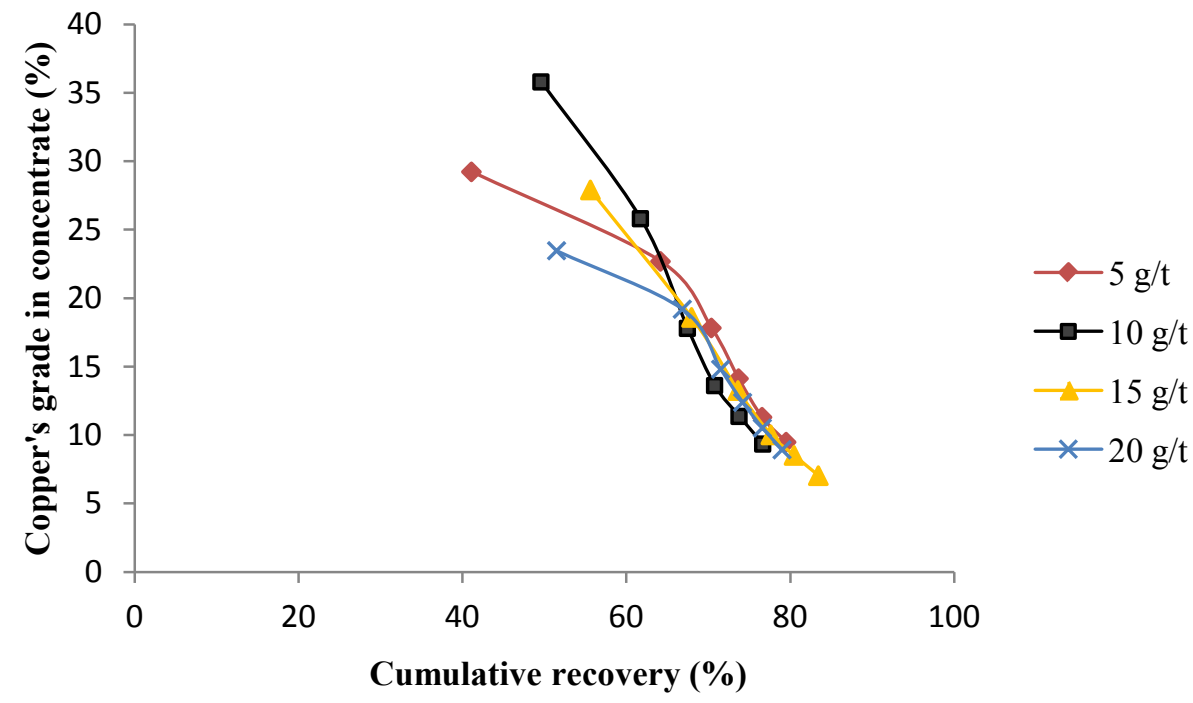

Figure 9 Effect of $\mathrm{Pb}\left(\mathrm{NO}_{3}\right)_{2}$ addition on copper recovery.

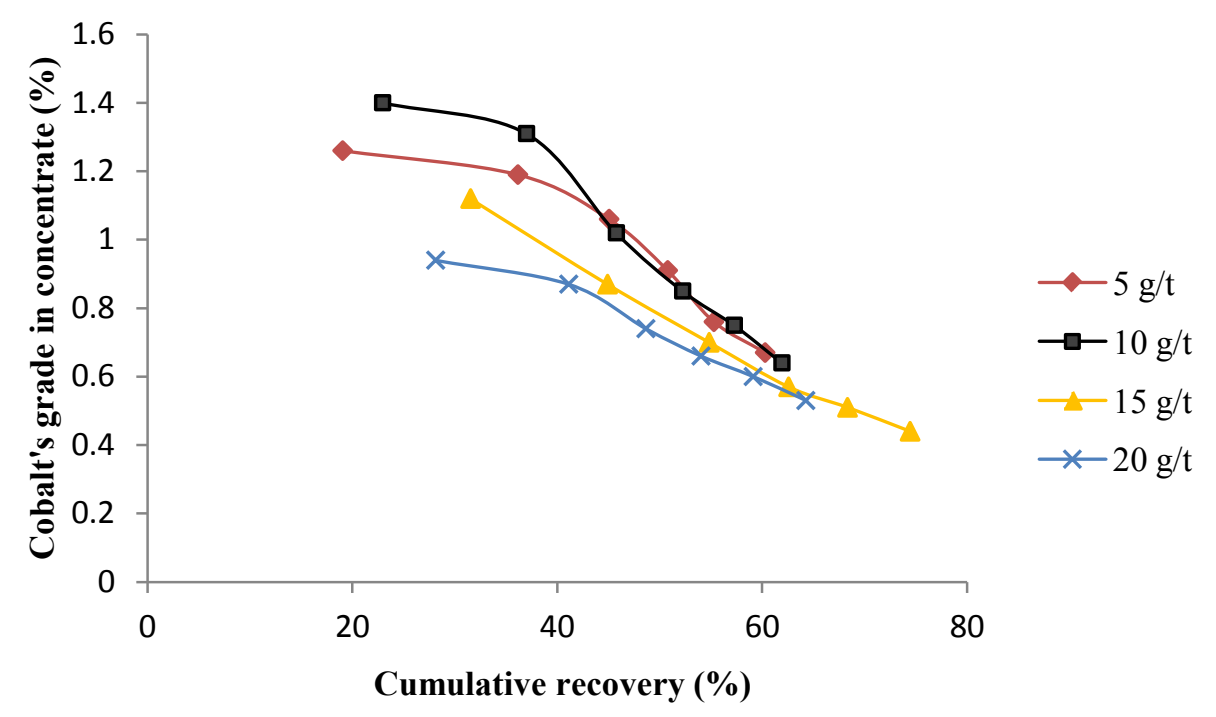

Figure 10 Effect of $\mathrm{Pb}\left(\mathrm{NO}_{3}\right)_{2}$ conditioning on cobalt recovery. 


\section{Influence of sulfidiser's diminution}

Improvement of selectivity produced by the addition of $\mathrm{Pb}\left(\mathrm{NO}_{3}\right)_{2}$ has suggested the possibility of reduction of sulfidiser consumption. Thus, 1,500, 2,000, 2,500, and 3,000 g/t were used to envisage the diminution of NaHS. Table 5, Figures 11 and 12 show the results for copper and cobalt, respectively.

According to the obtained results, the diminution of NaHS decreases flotation performances due to the depreciation of sulfurizing activity.

Table 6 Diminution of $\mathrm{NaSH}$ dose on recoveries of both Copper and Cobalt.

\begin{tabular}{ccccccc}
\hline \multirow{2}{*}{ Dose of NaSH $(\mathbf{g} / \mathbf{t})$} & \multicolumn{3}{c}{ Copper analysis (\%) } & \multicolumn{3}{c}{ Cobalt analysis (\%) } \\
\cline { 2 - 7 } & Feed & Concentrate & Final recovery & Feed & Concentrate & Final recovery \\
\hline 1,500 & 5.75 & 3.52 & 71.39 & 1.63 & 1.28 & 47.58 \\
2,000 & 19.41 & 6.76 & 84.1 & 0.69 & 0.43 & 68.28 \\
2,500 & 21.27 & 7.89 & 81.87 & 0.69 & 0.43 & 62.26 \\
3,000 & 29.23 & 9.49 & 79.51 & 1.26 & 0.67 & 60.27 \\
\hline
\end{tabular}

Another fact is that the diminution of sulfur ions leads to the diminution of created hydrophobic surfaces which rending the flotation non-selective and poor. However, the dose of 3,000 g/t was retained as optimal producing $9.49 \%$ Copper and $0.67 \%$ Cobalt with yields of 79.51 and $60.27 \%$, respectively.

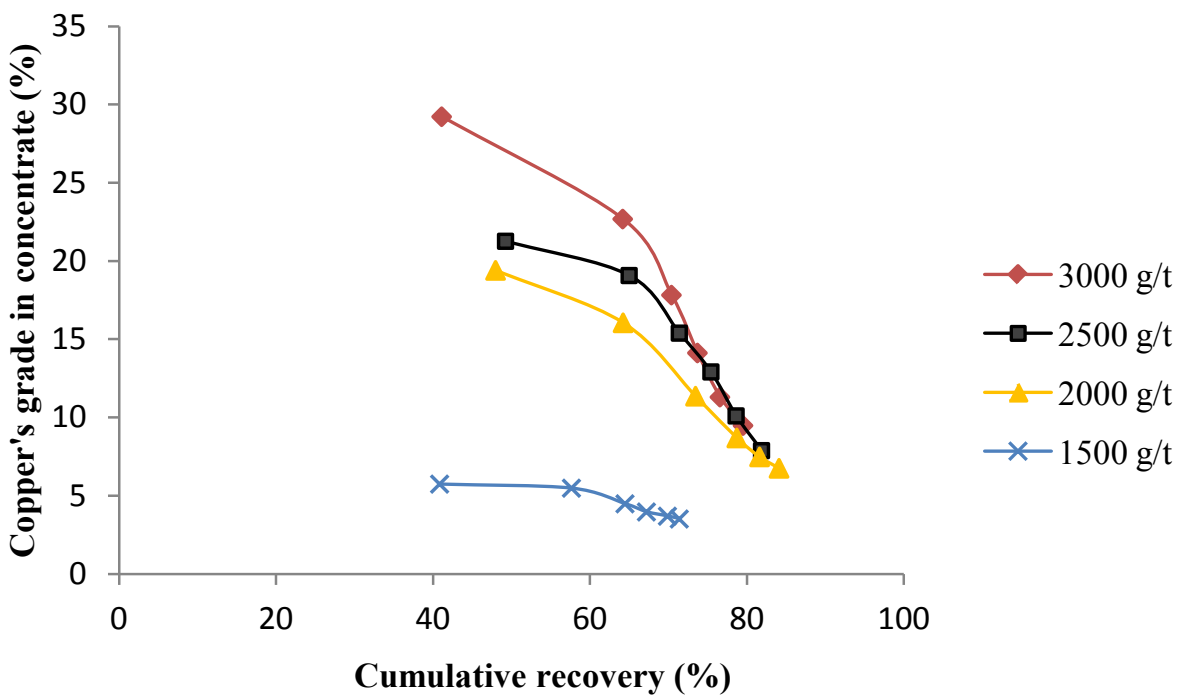

Figure 11 Influence of NaHS diminution on copper recovery. 


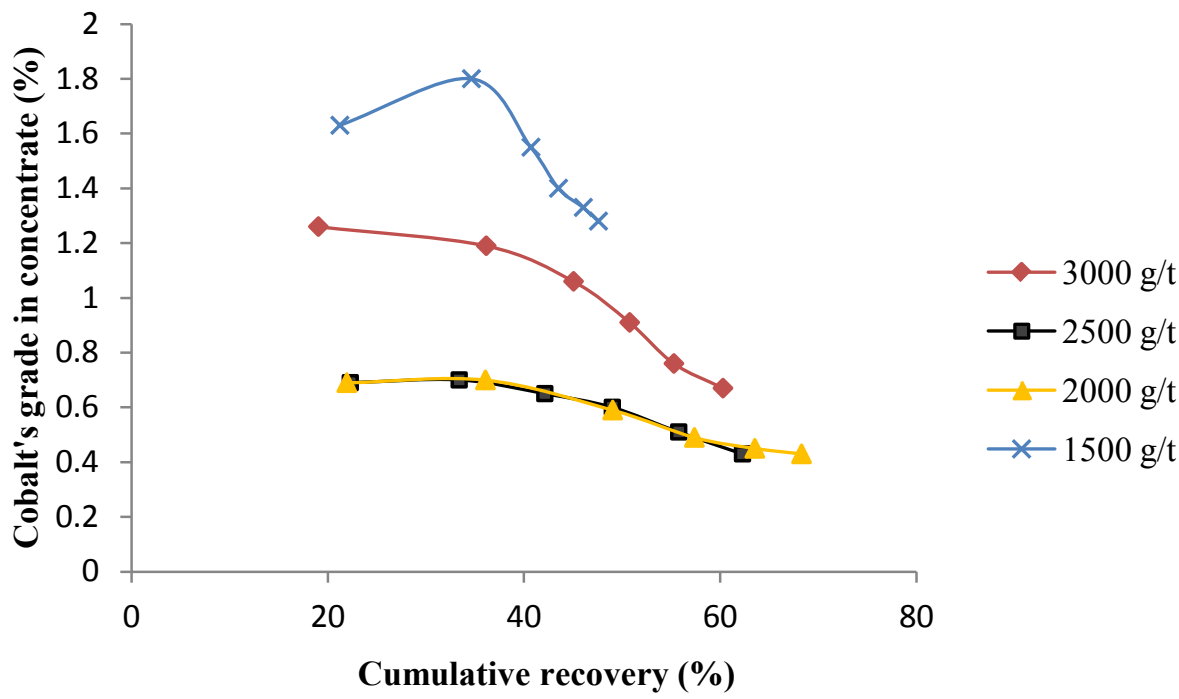

Figure 12 Influence of NaHS diminution on cobalt recovery.

\section{Comparison between the use of $\mathrm{Pb}\left(\mathrm{NO}_{3}\right)_{2}$ results and reference results}

The reference results (Figures 3 and 4) were obtained by using reference conditions shown above: PAX (300 g/t), $\mathrm{NaSiO}_{3}(300 \mathrm{~g} / \mathrm{t}), \mathrm{G} 41(90 \mathrm{~g} / \mathrm{t})$, MIX (300 g/t), and NaHS (3,000 g/t). The result by using $\mathrm{Pb}\left(\mathrm{NO}_{3}\right)_{2}$ was obtained at $25 \mathrm{~g} / \mathrm{t}$ conditioned with $\mathrm{Na}_{2} \mathrm{SiO}_{3}$ for $5 \mathrm{~min}$ followed by the addition of $5 \mathrm{~g} / \mathrm{t}$ in the $2^{\text {nd }}$ fraction and $3,000 \mathrm{~g} / \mathrm{t}$ of NaHS (Figures 11 and 12).

As shown in Figure 13, $\mathrm{Pb}\left(\mathrm{NO}_{3}\right)_{2}$ increases metals recoveries with a notable improvement in the quality of concentrates and yields.
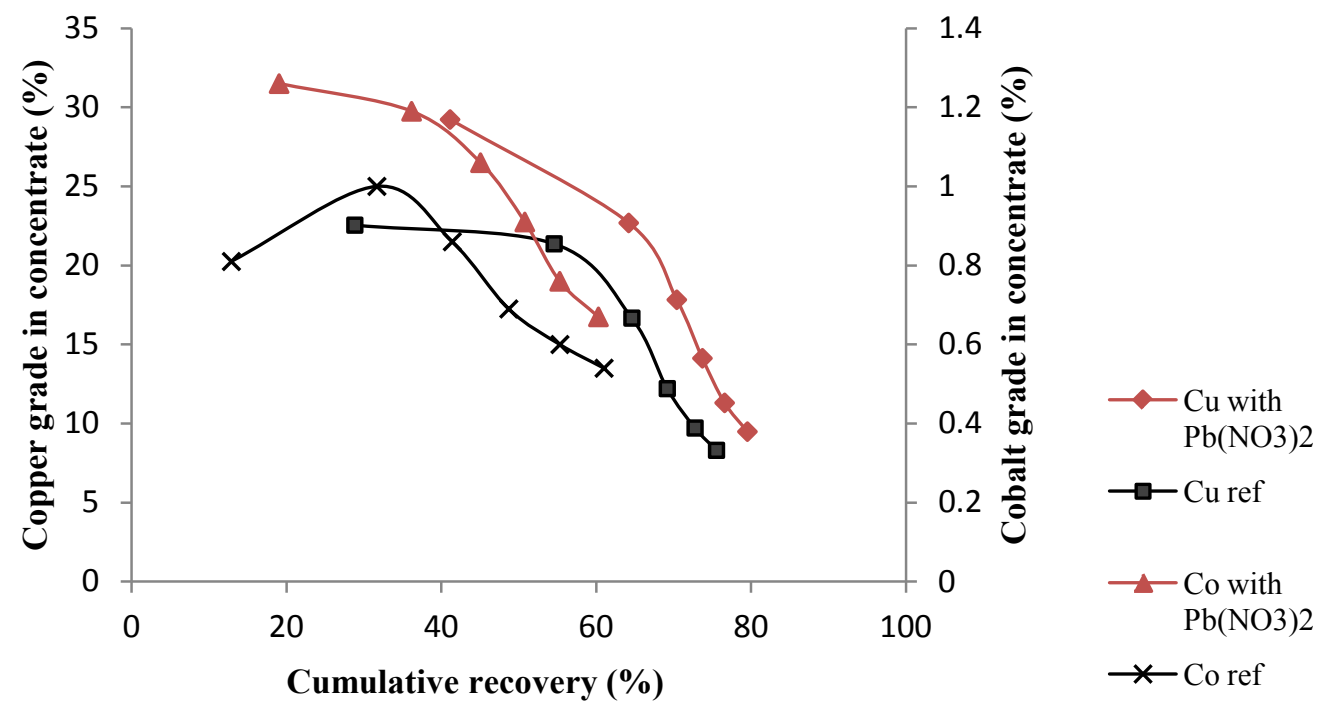

Figure 13 Comparative flotation with and without $\mathrm{Pb}\left(\mathrm{NO}_{3}\right)_{2}$. 
The effects of $\mathrm{Pb}\left(\mathrm{NO}_{3}\right)_{2}$ can be resumed on the following:

1) After the addition of NaHS, there are formations of both copper sulfide $(\mathrm{CuS})$ and lead sulfide $(\mathrm{PbS})$

2) After the addition of PAX, xanthate ions react with $\mathrm{CuS}$ and PbS, Eqs. (5) and (1);

$C u S+2 X^{-} \rightarrow C u X_{2}+S^{0}+2 e^{-}$

3) View the liberation of $\mathrm{OH}^{-}$ions from malachite, there are transfers of $\mathrm{Cu}(\mathrm{OH})^{+}$into $\mathrm{CuS}$ and of $\mathrm{Pb}(\mathrm{OH})^{+}$into $\mathrm{PbS}$, Eq. (6)

$\mathrm{PbS}+\mathrm{Cu}(\mathrm{OH})^{+} \rightleftarrows \mathrm{CuS}+\mathrm{Pb}(\mathrm{OH})^{+}$

4) It can be supposed a double activation: the $1^{\text {st }}$ concerns $\mathrm{PbS}$ on $\mathrm{CuS}$ surface and the $2^{\text {nd }}$ concerns $\mathrm{CuS}$ on $\mathrm{PbS}$ surface (Figures 14A and 14B).

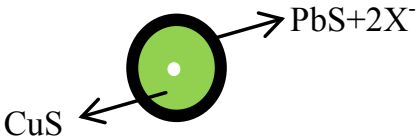

(A)

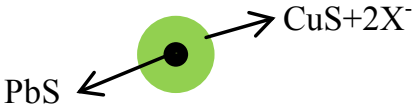

(B)

Figure 14 Double activation during flotation using $\mathrm{Pb}\left(\mathrm{NO}_{3}\right)_{2}$ as an activator; (A) $\mathrm{PbS}$ on $\mathrm{CuS}$ surface; (B) $\mathrm{CuS}$ on $\mathrm{PbS}$ surface.

Those 4 points should be confirmed by further studies including the adsorption mechanism of xanthate by FTIR and SEM techniques.

\section{Conclusions}

In contrast to this study, the following conclusions can be made regarding $\mathrm{Pb}\left(\mathrm{NO}_{3}\right)_{2}$ during a copper-cobalt oxide ore.

- The use of $\mathrm{Pb}\left(\mathrm{NO}_{3}\right)_{2}$ as an activator has favored the improvement of copper and cobalt flotation obtaining high-grade concentrates in comparison with reference flotation.

- The optimal dose was at $25 \mathrm{~g} / \mathrm{t}$, conditioned with $300 \mathrm{~g} / \mathrm{t}$ of $\mathrm{Na}_{2} \mathrm{SiO}_{3}$ during $5 \mathrm{~min}$, followed by the addition of $5 \mathrm{~g} / \mathrm{t}$ of $\mathrm{Pb}\left(\mathrm{NO}_{3}\right)_{2}$ in the $2^{\text {nd }}$ fraction.

- At optimal conditions, concentrates have been obtained at $9.49 \%$ Copper and $0.67 \%$ Cobalt with yields of 79.51 and $60.27 \%$, respectively.

- As a hypothesis, after the addition of lead ions, it could be observed the adsorption of generated product $\mathrm{PbS}$ on the mineral surfaces increasing the number of active sites. On another hand, $\mathrm{CuAX}$ generated played the role of activator towards $\mathrm{PbS}$, which increased the selectivity.

It is suggested that the interaction between copper and lead cations be studied with variable potential values.

\section{Acknowledgment}

The authors would like to thank the company Gecamines (Haut-Katanga Province, the Democratic Republic of the Congo) for acceptance, and the metallurgical and chemical department for the preparation of samples and analysis for the execution of the research and the writing of this paper. 
http://wjst.wu.ac.th

\section{References}

[1] MB Kime, J Ntambwe and J Mwamba. Laboratory evaluation of the flotation response of a copper cobalt oxide ore to gasoil-rinkalore mixtures. WASET, Int. J. Geol. Environ. Eng. 2015; 9, 3.

[2] LM Shengo, S Gaydardzhiev, NM Kalenga. Malachite and heterogenite behaviour during the locked-cycle recycling of process water in flotation of copper-cobalt oxide ores. Int. J. Miner. Process. 2016; 157, 152-62.

[3] MM Meschack. Recovery of copper and cobalt in the comparative flotation of a sulfide ore using xanthate and dithiophosphate as collectors. Int. J. Eng. Appl. Sci. 2019; 6, 26-9.

[4] SM Bulatovic. Handbook of flotation reagents: Chemistry, theory and practice flotation of sulfide ores. Vol I. Elsevier Science \& Technology Books, 2007, p. 105-78.

[5] P Blazy. Ores valorisation, mineralurgy manual. University Press of Paris, French, 1970.

[6] BA Wills and T Napier-Munn. Mineral processing technology: An introduction to the practical aspects of ore treatment and mineral recovery. $7^{\text {th }}$ eds. Oxford: Butterworth-Heinemann, 2006.

[7] L Levard. 1971, Study of floatability of cobalt oxide. Ph.D. Thesis. Catholic University of Louvain, Louvai, Belgium.

[8] BA Wills. Mineral processing technology: An introduction to the practical aspects of ore treatment and mineral recovery. Butterworth-Heinemann, 2011.

[9] W Chen and Z Ye. Study on wolframite flotation activated by lead nitrate. Chin. J. Nonferrous Met. 1999; 9, 13-17.

[10] X Fan and $\mathrm{N}$ Rowson. The effect of $\mathrm{Pb}\left(\mathrm{NO}_{3}\right)_{2}$ on ilmenite flotation. Miner. Eng. 2000; 13, 205-15.

[11] Z Gang, W Shuai and Z Hong. Study on the activation of scheelite and wolframite by lead nitrate. Minerals 2015; 5, 247-58.

[12] R Houot and P Raveneau. Activation of sphalerite flotation in the presence of lead ions. Int. J. Miner. Process. 1992; 35, 253-71.

[13] JD Miller, R Kappes, GL Simmons and KM LeVier. Pyrite activation in amyl xanthate flotation with nitrogen. Miner. Eng. 2006; 19, 659-65.

[14] X Liuyin and L Brandon. A Tof-SIMS analysis of the effect of lead nitrate on rare earth flotation. Miner. Eng. 2015; 70, 119-29.

[15] RD Plessis, DG Kotlyar, GL Simmons and JD Miller. The effect of activation on the low potential hydrophobic state of pyrite in amyl xanthate flotation with nitrogen. SME Preprint 2002; 2, 154-5.

[16] J Leppinen, K Laajalehto, I Kartio and E Souninen. FTIR and XPS studies of surface chemistry of pyrite in flotation. Int. Miner. Process. Congr. XIXth So. Min. Metal. Explor. Littleston 1995; 3, 35-8.

[17] N Zohir and B Djamel. Study of Xanthane (KAX) adsorption on galena: Separation by flotation. Online J. Sci. Tech. 2013; 3, 188-96.

[18] MC Fuerstenau. Principles of flotation. Vol. 91. South African Institute of Mining and Metallurgy, Johannesburg, 1982.

[19] GW Poling, MC Fuerstenau and R Woods. Electrochemistry of Sulphide Flotation. Vol. I. AIME, New York, 1976, p. 334-5.

[20] NP Finkelstain. The activation of sulphide minerals for flotation: A revew. Int. Miner. Process. 1997; 52, 81-92.

[21] JD Miller and JJ Kellar. Internal reflection spectroscopy for FTIR analysis ofcarboxylate adsorption by semi soluble salt minerals, advances in flotation technology. Society for Mining, Metallurgy and Exploration, Littleton, 1999, p. 45-59.

[22] E Muzenda. An investigation into the effect of water quality on flotation performance. World Acad. Sci. Eng. Tech. 2010; 69, 237-41.

[23] R Pérez-Garibay, N Ramírez-Aguilera, J Bouchard and J Rubio. Froth flotation of sphalerite: Collector concentration, gas dispersion and particle size effects. Miner. Eng. 2014; 57, 72-8. 